\title{
Gökkuşağı Alabalıklarından İzole Edilen Potansiyel Probiyotik Bakterilerin Hidrofobisite, Safra ve pH Töleranslarının Tespiti
}

\author{
Behire Işıl Didinen', Alper Çiftci², Esengül Morsümbül ${ }^{1}$ \\ ${ }^{1}$ Süleyman Demirel Üniversitesi, Su Ürünleri Fakültesi, Su Ürünleri Yetişstiriciliği. Anabilim Dall, Isparta,Türkiye; \\ ${ }^{2}$ Ondokuz Mayls Üniversitesi, Veteriner Fakültesi, Mikrobiyoloji Anabilim Dall, Samsun, Türkiye
}

Geliş Tarihi / Received: 11.09.2017, Kabul Tarihi / Accepted: 11.12.2017

\begin{abstract}
Özet: Bu çalışmada, gökkuşağı alabalıklarının bağırsaklarından izole edilen bakterilerin, Lactococcus garvieae’ye karşı in vitro antagonsitik etkileri, hidrofobisiteleri, safra tuzlarına ve düşük $\mathrm{pH}$ şartlarına töleransları araştırıldı. Bu amaçla sağlıklı 20 adet gökkuşağı alabalığının (250 g) bağırsaklarından bakterilerilerin izolasyonu yapıldı. İzole edilen 157 adet bakterinin Agar Kuyu Difüzyon yöntemi kullanılarak L. garvieae ya karş1 antagonistik aktiviteleri belirlendi. Dört izolat $L$. garviea'ye karşı in vitro antagonistik etki gösterdi. Antagonistik suşların fenotipik özelliklerinin saptanmasında geleneksel testler, API 20 NE ve API STREP test kitleri; moleküler identifiksyon için, L. garvieae spesifik PCR ve 16S rRNA gen sekans analizi kullanıldı. Çalışmanın sonucunda, aday probiyotik suşlar, Aeromonas sobria (TUB/2013/L63), Bacillus sp. (TUB/2013/L97) ve L.garvieae (TUB/2013/L32) hidrofobik (bağırsak epitel hücrelerine tutunma kabiliyetinde), safra tuzlarına ve düşük pH şartlarına(balığın sindirim sisteminde hayatta kalma özelliğinde) töleranslı bulundu.
\end{abstract}

Anahtar kelimeler: Aeromonas, Bacillus, Lactococcus garvieae, Oncorhyncus mykiss, Probiyotik, hidrofobisite, safra ve $\mathrm{pH}$ tölerans1

\section{Determination of Hydrophobicity, Bile and pH Tolerances of Potential Probiotics Isolated From Rainbow Trout (Oncorhynchus mykiss, Walbaum 1792)}

\begin{abstract}
In this study, bacterial isolates from the intestines of rainbow trout were investigated for in vitro antagonistic effects against Lactococcus garvieae, hydrophobicity, bile salts and low $\mathrm{pH}$ conditions. For this purpose, bacteria were isolated from the intestines of 20 healthy rainbow trout $(250 \mathrm{~g})$. Antagonistic activities of 157 bacterial isolates against L. garvieae by Agar Well Diffusion method. Four isolates showed antagonistic effect against L. garviea in vitro. Phenotypic characteristics of antagonistic strains were determined by conventional tests, API 20 NE and API STREP test kits. For molecular identification, L. garvieae specific PCR and 16S rRNA gene sequence analysis were used. As a result of the study, candidate probiotic strains, Aeromonas sobria (TUB / 2013 / L63), Bacillus sp. (TUB / 2013 / L97) and L. garvieae (TUB / 2013 / L32) were found hydrophobic (ability to bind to intestinal epithelial cells), bile salts and low pH conditions (ability of the fish to survive in the digestive system).
\end{abstract}

Key words: Fish, Probiotic, Hydrophobicity, Bile and pH Tolerances

\section{Giriș}

Hemorojik septisemi ile karakterize sistemik bir enfeksiyon olan Laktokokkozis özellikle su sicaklığ1nın $16^{\circ} \mathrm{C}$ 'nin üzerine çıktığı yaz aylarında etkili olmakta ve gökkuşağı alabalıklarında her boyda (porsiyonluk ve anaçlar dahil) yüksek mortaliteye neden olması sebebiyle balık işletmelerinde büyük ekonomik kayıplar yaratmaktadır [15]. Laktokokkozis ülkemizde ise ilk defa 2001 yılında Ege bölgesindeki gökkuşağı alabalığı işletmelerinde görülmüş ve o tarihten itibaren ülkemizde görülme sıklığı artmıştır $[2,11,19]$. Su ürünleri yetiştiriciliğinde Lactococcus garvieae salgınları antibiyotiklerle tedavi edilmektedir. Bununla birlikte, tedaviler sıklıkla başarısız olmakta ve antibiyotiklerin bilinçsiz kullanımı antibiyotik direncinin artmasına sebep olmaktadır [24].

Akuakültürde hastalıkların görülme sıklığı$\mathrm{n}$ 1 azaltmak için, antibiyotik tedavilerine alternatif olarak probiyotiklerin kullanımına ilişkin çalışmalar artmıştır [5]. Potansiyel probiyotik suşlar farklı etki mekanizmaları ve özellikler göstermektediler. Bu etki mekanizmaları ve özellikler arasında $\mathrm{pH}^{\prime} \mathrm{y} 1$ düşürmek suretiyle patojenlere antagonistik etki gösterme, antibakteriyel maddeler üretme, besinler ve tutunma bölgeleri için rekabet, vitamin ve enzim üretmeleri, kolonizasyon ya da tutunma yetenekleri ve bağışıklık sistemini güçlendirme yer almaktadır $[1,12]$. 
Probiyotik suşlar, sucul hayvanların kendi mikrofloralarından ya da bulundukları ortamdan izole edilmektedir. Etkili probiyotik bakterilerin keşfedilmesi için, aday probiyotik bakteriler sıklıkla ön eleme işleminden geçirilirler [25]. Bu işlem, öncelikle in vitro antagonizm, tutunma ve bağırsak mukusunda gelişme özelliklerinin belirlenmesi ile başlamaktadir $[14,26]$.

$\mathrm{Bu}$ çalışmada, gökkuşağı alabalıklarının bağrsak mikroflorasından izole edilen bakterilerin in vitro şartlar altında L. garvieae'ya karşı antogonistik etkileri, tür düzeyinde teşhisleri, balıkların mide bağırsak kanalında hayatta kalabilme yetenekleri (safra tuzları ve düşük pH şartlarına tolerans) ve bağırsak epitel hücrelerine tutunma özellikleri (hidrofobisite) belirlenmiştir.

\section{Materyal ve Metot}

Bu çalışmada kullanılan 20 adet sağlıklı gökkuşağ alabalığı (ort.250 g) Isparta ili sınırları içerisindeki iki işletmeden temin edildi.

\section{Aday probiyotik bakterilerin fenotipik karakterizasyonları}

Tüm antagonistik özellik gösteren suşların ilk olarak koloni morfolojileri belirlendi. Daha sonra gram boyama, hareket, sitokrom oksidaz, katalaz üretimi ve O/F testleri yapıldı. Şuşların diğer fenotipik özelliklerinin belirlenmesinde API 20 Strep ve API 20 NE hızlı teşhis kitleri (bioMe'rieux) kullanıldı.

\section{Aday probiyotik bakterilerin moleküler analizi}

L. garvieae spesifik PCR: İzolatların DNA ekstraksiyonları prensibi spin kolon ile filtrasyon sistemine dayanan ticari DNA ekstraksiyon kiti (Thermo Scientific, GeneJET Genomic DNA Purifikasyon Kiti) kullanılarak üretici firmanın talimatlarına göre yapıldı. L. garvieae'nın moleküler identifikasyonu tür spesifik pLG-1 (5'-CATAACAATGAGAATCGC-3') ve pLG-2 (5'-GCACCCTCGCGGGTTG-3') oligonukleotid primer setinin kullanıldı ${ }_{1}$ PCR metodu ile gerçekleştirildi [27]. Bu amaçla PCR amplifikasyonunda DEPC'li su, 1xPCR solüsyonu, $1.5 \mathrm{mM} \mathrm{MgCl}_{2}$, herbir dNTP'den $0.2 \mathrm{mM}, 1.0$ $\mathrm{U}$ Taq polimeraz (Fermentas), $1 \mu \mathrm{M}$ her bir primer ve $5 \mu 1$ hedef DNA içeren $25 \mu 1$ 'lik PCR karışımı oluşturuldu. Oluşturulan bu karışım Thermo PxE termal çevirici (Thermo Scientific) içerisinde $94^{\circ} \mathrm{C}^{\prime} \mathrm{de} 3 \mathrm{dk}$ ön denatürasyonu takiben $94^{\circ} \mathrm{C}^{\prime} \mathrm{de} 1 \mathrm{dk}$ denatürasyon, $55^{\circ} \mathrm{C}^{\prime} \mathrm{de} 1 \mathrm{dk}$ primer bağlanmas $1,72^{\circ} \mathrm{C}^{\prime}$ de 1.5 dk uzama olmak üzere 35 siklus ve $72^{\circ} \mathrm{C}^{\prime} \mathrm{de} 10 \mathrm{dk}$ sonuzama koşullarında amplifikasyon işlemine tabi tutuldu. PCR amplifikasyonu sonrası oluşan ürünler etidium bromid $(2 \mathrm{mg} / \mathrm{ml})$ içeren \% 1,5'luk agaroz jel elektroforezi sonrasinda UV transilluminatör ile görüntülendi. Sonuçta L. garvieae spesifik 1100 bp'lik amplifikasyon ürününün görülmesi pozitif sonuç olarak değerlendirildi. PCR çalışmasında pozitif kontrol olarak L. garvieae ATCC 43921 suşu, negatif kontrol olarak ta distile su kullanıld1.

16S rRNA sekans analizi: L. garvieae spesifik PCR ile identifiye edilemeyen izolatların 16S rRNA gen bölgesinin sekans analizi Macrogen (Seoul, Kore) firmasinın 16S rRNA tam sekanslama servisi tarafindan Applied Biosystems 3730xl DNA Analyzer kullanılarak gerçekleştirildi. Özetle, izolatlara ait 16S rRNA gen bölgesi 27F (AGAGTTTGATCMTGGCTCAG) ve 1492R (TACGGYTACCTTGTTACGACTT) üniversal primerlerinin kullanılarak PCR ile amplifiye edildi. PCR ürünü saflaştırıldiktan sonra 785F (GGATTAGATACCCTGGTA) ve 907R (CCGTCAATTCMTTTRAGTTT) primerleri kullanılarak sekans analizi gerçekleştirildi. Elde edilen sekans dizgileri Genbank kütüphanesinde bulunan referans sekanslar ile Basic Local Alignment Search Tool (BLAST) kullanılarak karşılaştırıldı.

\section{Potansiyel Probiyotik Bakterilerin İzolasyonu ve L. garvieae'ya Karşı in vitro Antagonistik Etkisinin Belirlenmesi}

Çalışmada L. garvieae'ya karşı antagonistik etki gösteren aday probiyotik bakterilerin seçimi yapıld1. Bu amaçla antagonistik etki gösterebilecek aday probiyotik bakterilerilerin izolasyonu sağliklı 20 adet gökkuşağı alabalıkların (ort. 250g) bağırsaklarından yapıldı. Bunun için bağırsaklar steril şartlar altında kesilip Steril Peptonlu Su ile homojenize edildikten sonra seri dilüsyonları $\left(10^{-1}-10^{-8}\right)$ hazırland 1 ve Triptik Soy Agar (TSA)'a ekimler yapılarak, $22^{\circ} \mathrm{C}$ 'de 48 saat inkübe edildi [6]. Balıkların bağırsak mikroflorasından izole edilen bakterilerin L. garvieae 'ya karş1 antagonistik etkilerinin araşt1rılmasında Agar Kuyu Difüzyon yöntemi kullanıldı [13]. 


\section{Hidrofobisite Testi}

Aday probiyotik bakterilerin hidrofobisitelerini belirlemek için \%0.03 Kongo Kırmızısı (Sigma-Aldrich) karıştırılmış TSA hazırlandı. Kongo kırmızısı TSA'nın sterilizasyonundan sonra eklendi. Aday probiyotik bakteriler Kongo kirmızısı ilave edilen TSA'ya ekildi ve $25^{\circ} \mathrm{C}^{\prime}$ de 24 saat inkübe edildi. Kırmızı koloniler pozitif (hidrofobik) ve beyaz veya renksiz koloniler ise negatif (non-hidrofobik) olarak değerlendirildi [23].

\section{Safra tuzlarına ve düşük pH şartlarına tolerans Testleri}

Aday probiyotik bakterilerin PBS içerisindeki süspansiyonlar1 $10^{7} \mathrm{kob} / \mathrm{ml}$ olarak hazırlandı. Gökkuşağ1 alabalıklarından safra kesesinin patlatılmasıyla safra örnekleri toplandı ve kullanılıncaya kadar $-20^{\circ} \mathrm{C}$ ' de sakland1. Bakteriyel süspansiyon, $\% 0,0.6$, 1 ve 1.5 safra içeren PBS içerisine inoküle edildi. Örnekler $22^{\circ} \mathrm{C}$ 'de 1.5 saat inkübe edildikten sonra steril PBS içinde seyreltilerek, TSA'da bakteri sayımı yapıldı. Aday probiyotik bakterilerin farklı $\mathrm{pH}$ şartlarına töleransının belirlenmesi için farklı $\mathrm{pH}$ değerlerine ( $\mathrm{pH} 2-7)$ sahip PBS içerisinde $10^{7} \mathrm{kob} /$ $\mathrm{ml}$ olarak hazırlanan süspansiyonları $22^{\circ} \mathrm{C}$ 'de 1.5 saat inkübe edildikten sonra steril PBS içinde seyreltilerek TSA'da bakteri sayımı yapıldı $[4,20]$.

\section{İstatistiksel hesaplamalar}

Elde edilen veriler (bakterilerin safra ve $\mathrm{pH}$ toleransları) SPSS 17.0 paket programinda Anova testi ile değerlendirildi (SPSS Inc, Chicago, IL, USA). Parametrelerin önem dereceleri karşılaştırılırken Duncan çoklu karşılaştırma testi kullanıldı ve önem düzeyi $\mathrm{P}=0,05$ olarak seçildi.

\section{Bulgular}

\section{Aday Probiyotik Bakterilerin Fenotipik Karakterizasyonları}

L. garvieae' ya karşı inhibitör aktivite gösteren bakterilerin geleneksel metotlarla, API 20 Strep ve API 20 NE hızlı teşhis kitleriyle belirlenen belirlenen fenotipik özellikleri Tablo 1 ve Tablo 2 'te verilmiştir.

\section{Aday Probiyotik Bakterilerin Moleküler Analizi}

L. garvieae spesifik PCR analizi sonucu TUB/2013/ L32 ve TUB/2013/L95 no'lu izolatların L. garvie- ae spesifik 1100 bp amplifikasyon ürünü verdiği, TUB/2013/L63 ve TUB/2013/L97 no'lu izolatların ise herhangi bir amplifikasyon ürünü vermediği saptand1 (Şekil 4.3.). Dolayısıla TUB/2013/L32 ve TUB/2013/L95 no'lu izolatlar $L$. garvieae olarak identifiye edildi. TUB/2013/L63 ve TUB/2013/ L97no'lu izolatlar için sonraki aşamada gerçekleştirilen 16S rRNA gen bölgesi sekans analizi sonucu sirasılyla 1481 ve 590 bp uzunluğunda sekans dizileri elde edildi ve bu diziler GenBank'a (www.ncbi. nlm.nih.gov/genbank/) KT456272 ve KT456273 erişim numaraları ile kaydedildi. Elde edilen morfolojik, biyokimyasal ve sekans verilerine dayanılarak TUB/2013/L63 no'lu izolat A. sobria, TUB/2013/ L97no'lu izolat ise Bacillus sp. olarak identifiye edildi.

Tablo 1. L. garvieae'ya karşı inhibitör aktivite gösteren Gram Pozitif Kokların geleneksel metotlarla ve API 20 STREP ile belirlenen fenotipik özellikleri

\begin{tabular}{|c|c|c|}
\hline & TUB/2013/L32 & TUB/2013/L95 \\
\hline Gram boyama & Pozitif kok & Pozitif kok \\
\hline Hareket & - & - \\
\hline Oksidaz & - & - \\
\hline Katalaz & - & - \\
\hline $\mathrm{O} / \mathrm{F}$ Testi & $\mathrm{F}$ & $\mathrm{F}$ \\
\hline VP & + & + \\
\hline Hippurat hidrolizi & - & - \\
\hline Eskulin hidrolizi & + & + \\
\hline Piyrrolidonil arylamidaz & + & + \\
\hline$\alpha$-Galaktosidaz & - & - \\
\hline$\beta$-Glukuronidaz & - & - \\
\hline$\beta$-Galaktosidaz & - & - \\
\hline Alkalin fosfataz & - & - \\
\hline Lösin arilamidaz & + & + \\
\hline Arjinin dihidrolaz & + & + \\
\hline \multicolumn{3}{|l|}{ Asit üretimi: } \\
\hline Riboz & + & + \\
\hline L-Arabinoz & - & - \\
\hline Mannitol & - & - \\
\hline Sorbitol & - & - \\
\hline Laktoz & - & - \\
\hline Trehaloz & + & + \\
\hline İnülin & - & - \\
\hline Rafinoz & - & - \\
\hline Nişasta & + & + \\
\hline Glikojen & - & - \\
\hline
\end{tabular}


Tablo 2. L. garvieae'ya karşı inhibitör aktivite gösteren diğer izolatların geleneksel metotlarla ve API 20 NE ile belirlenen fenotipik özellikleri

\begin{tabular}{|c|c|c|}
\hline & TUB/2013/L6 & TUB/2013/L97 \\
\hline Gram boyama & Negatif basil & Pozitif basil \\
\hline Hareket & + & - \\
\hline Oksidaz & + & - \\
\hline Katalaz & + & + \\
\hline $\mathrm{O} / \mathrm{F}$ Testi & $\mathrm{F}$ & $\begin{array}{l}\text { Glikozu } \\
\text { kullanmıyor }\end{array}$ \\
\hline Nitrate indirgeme & + & - \\
\hline İndol üretimi & + & - \\
\hline Glikoz asidifikasyon & + & - \\
\hline Arjinin dihidrolaz & + & + \\
\hline Üre hidrolizi & - & - \\
\hline Eskülin hidrolizi & + & + \\
\hline Jelatin hidrolizi & + & - \\
\hline$\beta$ - galaktosidaz & + & + \\
\hline Glikoz asimilasyonu & + & - \\
\hline Arabinoz asimilasyonu & + & - \\
\hline Mannoz asimilasyonu & + & - \\
\hline Mannitol asimilasyonu & + & - \\
\hline N-Acetyl Glusomine & + & - \\
\hline $\begin{array}{l}\text { Maltose Glusomine } \\
\text { asimilasyonu }\end{array}$ & + & - \\
\hline $\begin{array}{l}\text { Gluconate Glusomine } \\
\text { similasyonu }\end{array}$ & + & + \\
\hline $\begin{array}{l}\text { Caprate Glusomine } \\
\text { asimilasyonu }\end{array}$ & - & - \\
\hline $\begin{array}{l}\text { Adipate Glusomine } \\
\text { asimilasyonu }\end{array}$ & - & - \\
\hline $\begin{array}{l}\text { Malate Glusomine } \\
\text { asimilasyonu }\end{array}$ & + & - \\
\hline $\begin{array}{l}\text { Citrate Glusomine } \\
\text { asimilasyonu }\end{array}$ & + & - \\
\hline $\begin{array}{l}\text { Phenyl acetate Glusomine } \\
\text { asimilasyonu }\end{array}$ & & - \\
\hline
\end{tabular}

Potansiyel Probiyotik Bakterilerin L. garvieae'ya Karşı in vitro Antagonistik Etkisinin Belirlenmesi

Bu çalıșmada, gökkuşağı alabalıklarının bağırsaklarından izole edilen 157 suştan 4'ünün L. garvie$a e^{\prime}$ ya karş1 in vitro antagonistik etki gösterdikleri saptand1 (Tablo 3).

\section{Potansiyel Probiyotik Bakteri Suşlarının Hidrofobisite, $\mathbf{p H}$ ve Safra Töleransları}

L. garvieae (TUB/2013/L95) hariç, diğer antagonistik suşların hidrofobik özellikte, başka bir deyişle non spesifik olarak konakçının bağırsak epiteline tutunma kabiliyetlerinin oldukları belirlenmiştir. Antagonistik suşların tamamı, düşük $\mathrm{pH}$ şartlarına ve safra tuzlarına dirençli bulunmuşlardır (Tablo 4 ve Tablo 5$)(\mathrm{p}>0.05)$.

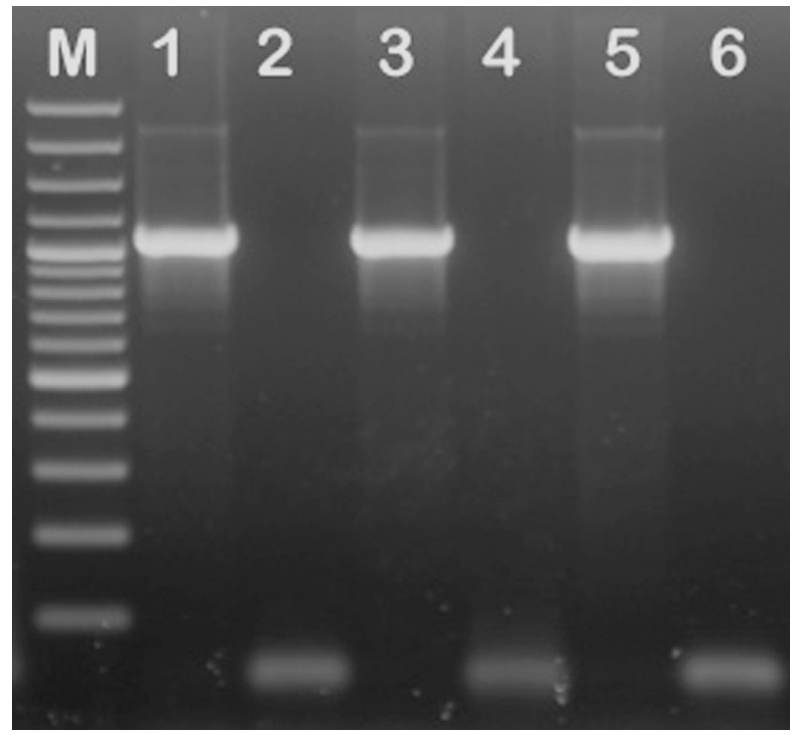

Şekil 1. L. garvieae spesifik PCR (1100 bp). M; Moleküler Belirteç (100 bp Plus DNA Ladder), 1; L. garvieae ATCC 43921, 2; Negatif Kontrol (Distile su), 3; TUB/2013/L32, 4; TUB/2013/L63, 5; TUB/2013/L95, 6; TUB/2013/L97

Tablo 3. L. garvieae 'ya karşı inhibitör aktivite gösteren bakteriyel izolatlar

\begin{tabular}{ll}
\hline İzolatlar & İnhibisyon zonu (mm) \\
\hline TUB/2013/L32 & 16 \\
TUB/2013/L95 & 8 \\
TUB/2013/L97 & 8 \\
TUB/2013/L63 & 8 \\
\hline
\end{tabular}

Tablo 4. Farklı pH şartlarında aday probiyotik suşların toleransi $\left(\log \mathrm{kob} / \mathrm{ml}, \mathrm{SD}^{*}\right)$

\begin{tabular}{lllll} 
pH & $\begin{array}{l}\text { L. garvieae } \\
\text { TUB/2013/L32 }\end{array}$ & $\begin{array}{l}\text { L. garvieae } \\
\text { TUB/2013/L95 }\end{array}$ & $\begin{array}{l}\text { Bacillus sp. } \\
\text { TUB/2013/L97 }\end{array}$ & $\begin{array}{l}\text { A.sobria } \\
\text { TUB/2013/L63 }\end{array}$ \\
\hline 7 & $7,59 \pm 0,65$ & $7,58 \pm 0,26$ & $7,39 \pm 0,45$ & $7,63 \pm 0,56$ \\
3 & $7,76 \pm 0,47$ & $7,8 \pm 0,40$ & $7,65 \pm 0,28$ & $7,79 \pm 0,49$ \\
\hline 2 & $7,82 \pm 0,34$ & $7,86 \pm 0,65$ & $7,14 \pm 0,67$ & $7,61 \pm 0,59$ \\
\hline
\end{tabular}

* Bakteri sayıları TSA'da belirlendi. Veriler ortalama (standart sapmalar) olarak verilmiştir. 
Tablo 5. Farklı safra konsantrasyonlarına aday probiyotik suşlarının toleransı ( $\log \mathrm{kob} / \mathrm{ml}, \mathrm{SD}^{*}$ )

\begin{tabular}{|c|c|c|c|c|}
\hline $\begin{array}{l}\% \\
\text { Safra }\end{array}$ & $\begin{array}{l}\text { L. garvieae } \\
\text { TUB/2013/L32 }\end{array}$ & $\begin{array}{l}\text { L. garvieae } \\
\text { TUB/2013/L95 }\end{array}$ & $\begin{array}{l}\text { Bacillus sp. } \\
\text { TUB/2013/L97 }\end{array}$ & $\begin{array}{l}\text { A.sobria } \\
\text { TUB/2013/L63 }\end{array}$ \\
\hline 0 & $6,90 \pm 0,54$ & $6,97 \pm 0,56$ & $5,73 \pm 0,84$ & $6,52 \pm 0,58$ \\
\hline 0.6 & $6,54 \pm 0,50$ & $7,03 \pm 0,48$ & $6,55 \pm 0,40$ & $7,20 \pm 0,95$ \\
\hline 1 & $6,14 \pm 0,31$ & $7,02 \pm 0,52$ & $7,05 \pm 0,73$ & $7,05 \pm 0,44$ \\
\hline 1.5 & $6,55 \pm 0,66$ & $7,27 \pm 0,47$ & $5,76 \pm 0,23$ & $7,24 \pm 0,84$ \\
\hline
\end{tabular}

* Bakteri sayıları TSA'da belirlendi. Veriler ortalama (standart sapmalar) olarak verilmiştir.

\section{Tartışma}

Patojen oldukları bilinen Vibrio spp., A. sobria ve A. hydrophila gibi bakterilerin apatojen suşları balık ve karides kültüründe probiyotik bakteri olarak kullanılmaktadır [7,14,17]. Sazan balıklarının (Cyprinus sp.) sindirim sisiteminden izole edilen A. sobria GC2 suşunun A.salmonicida, L.garvieae, S.iniae, V.anguillarum, V.ordalii ve Y.ruckeri'ye karş1 antagonistik etkileri saptanmıştır [7]. Bir çalışmada, ergin gökkuşağı alabalıklarının yetiştiricilik sularından izole edilen Vibrio sp. A3 ve A8 suşları ile Aeromonas sp. A1, A5 ve G1 suşlarının L. garvie-

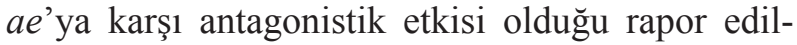
miştir [9]. Benzer şekilde, bu çalışmada gökkuşağ 1 alabalıklarının bağırsaklarından izole edilen $A$. sobria (TUB/2013/L63) suşunun L. garvieae' ya karş1 antagonistik etki gösterdiği saptanmıştır.

Çalışmamızda potansiyel probiyotik L. garvieae suşlarının, patojen L. garvieae'ye karşı antagonistik etkisi saptanmıştır. Benzer şekilde, daha önce yapılan çalışmalarda, gökkuşağ 1 alabalıklarının bağırsaklarından [10] ve yetiştiricilik suyundan [9] izole edilen $L$. garvieae suşlarının, patojen $L$. garvieae' yi inhibe edici özellik gösterdikleri belirtilmektedir.

Brunt ve ark. [7] gökkuşağı alabalıklarının sindirim sisteminden izole ettikleri Bacillus sp.'nin L. garvieae ve Streptococcus iniae'ye karş1 etki antagonistik gösterdiklerini bildirmişlerdir. Benzer şekilde, çalışmamızda Bacillus sp. (TUB/2013/ L97)'nin L. garvieae'ya karşı antagonistik etkisi saptanmıştır.

Bağırsak epitel hücrelerine tutunma kabiliyeti (konakçıya kolonizasyon), potansiyel probiyotik suşlar için önemli bir özelliktir. Pozitif hidrofobisite sonuçları bakterilerin bağırsak epitel hücrelerine tutunma kabiliyetlerinin olduğunu göstermektedir $[3,21]$. Bu çalışmada da, izole edilen L.garvieae (TUB/2013/L95) suşunun hidrofobisite göstermediği; diğer üç suşun (L. garvieae TUB/2013/L32, Bacillus sp. TUB/2013/L97 ve A.Sobria TUB/2013/ L63) hidrofobik özellikte oldukları saptanmıştır. Benzer şekilde, gökkuşağ 1 alabalıklarının yetiştiricilik sularından izole edilen $L$. garvieae ve Aeomonas spp. [9], hint sazanlarının (Labeo rohita) bağırsaklarından izole edilen Bacillus infantis' in [8] hidrofobik özellikte oldukları bildirilmiştir.

Yüksek ölçüde hidrofobik özelliğe sahip suşların asite ve safraya dirençli olmaları nedeniyle mide bağırsak boşluğu boyunca daha çok hayatta kalma kabiliyetine sahiptirler ve potansiyel olarak balığın bağırsak yüzeyine kolonize olabilmektedirler [18]. Probiyotik suş seçiminde kullanılan safra konsantrasyonları için araştırıcılar arasında bir fikir birliği sağlanamamıştır. Bazı araştırmacılar \%10 safra konsatrasyonuna kadar toleransin tespit edilmesini önerirken [18], diğer bir kısmı \%1'e kadar toleransin tespitinin yeterli olduğu görüşünü bildirmişlerdir [20]. Öyle ki, Balcázar ve ark. [4], salmonid balıklarda bağırsaktaki fizyolojik safra konsantrasyonunun \%0.4-1.3 arasında hesapladığını bildirmişlerdir. Bu nedenle, çalışmamızda aday probiyotik bakterilerin \% 0.6, 1 ve 1.5 safra konsatrasyonlarına toleransları araştırılmış ve antagonistik etki gösteren suşların tamamının safra tuzlarına tolerenslı oldukları saptanmıştır. Dharmaraj ve Rajendren [8], hint sazanlarının (Labeo rohita) bağırsaklarından izole etikleri Bacillus infantis' in \%2.5 safra konsatrasyonunda 3 saat sonra \%63.33'ünün hayatta kalabildiğini belirtmişlerdir. Benzer şeklide, Sansawat ve Thirabunyanon [22], tatlı su karideslerinin (Macrobrachium rosenbergii) mide-bağırsak kanallarından izole ettikleri B.subtilis $\mathrm{P} 33$ ve72 suşlarının \% 0.3 safra konsatrasyonunda 24 saat süreyle hayatta kalabildiklerini belirtmişlerdir. Ayrıca, Didinen ve ark. [10], gökkuşağı alabalıklarının bağırsaklarından izole ettikleri L. garvieae 1-3 suşunun \%2.5-10 safra konsatrasyonlarına tölerans gösterdiğini bildirmişlerdir.

Gökkuşağı alabalıklarının mide pH'larının 2.5-3.5 olduğu bildirilmiştir [16]. Bu nedenle aday probiyotik suşların bu aralıklardaki $\mathrm{pH}$ değerlerine toleranslı olması mideden geçişleri esnasında hayatta kalmalarını sağlayacağı düşünülmüştür. $\mathrm{Bu}$ 
çalışmada aday probiyotik suşların tamamının 2-3 pH şartlarında hayatta kalabildikleri saptandı. Dharmaraj ve Rajendren [8] de, hint sazanlarının (Labeo rohita) bağırsaklarından izole etikleri B.infantis'in 2 pH'da hayatta kalabildiğini bildirmişlerdir. Sansawat ve Thirabunyanon [22], tatlı su karideslerinin (Macrobrachium rosenbergii) mide-bağırsak boşluklarından izole edilen B.subtilis P33 and 72 suşlarının pH 2.5'da 3 saat süreyle hayatta kalabildiklerini belirtmişlerdir. Didinen ve ark. [10] aday probiyotik $L$. garvieae 1-3 suşunun $2.5 \mathrm{pH}$ şartlarında hayatta kalabildiğini belirtmişlerdir.

Sonuç olarak, bu çalışmada gökkuşağ 1 alabalıklarının bağırsaklarından izole edilen L.garvieae (TUB/2013/L32), L. garvieae (TUB/2013/ L95), Bacillus sp. (TUB/2013/L97) ve A.sobria (TUB/2013/L63) suşlarının L. garvieae'ya karş1 inhibitör etki gösterdiği saptanmıştır. Antagonistik suşlar arasında L.garvieae (TUB/2013/L95) hidrofobisite göstermemiştir. Diğer şuşlar in vitro şartlarda probiyotik (hidrofobik, yüksek safra ve düşük $\mathrm{pH}$ şartlarına dirençli olma) özellik göstermişlerdir. Gelecekteki çalışmalarda bu aday probiyotiklerin gökkuşağı alabalıklarında patojeniteleri belirlendikten sonra, balıkların yemlerine ilave edilerek $L$. garvieae'ye karşı hastalık direnci üzerindeki etkileri araştırılacaktır.

\section{KAYNAKLAR}

1. Aguirre-Guzmán G, Lara-Flores M, Sánchez-Martínez JG, Campa-Córdova AI, Luna-González A, (2012). The use of probiotics in aquatic organisms: A review. Afr J Microbiol Res. 6(23), 4845-4857.

2. Altun S, Diler O, Adiloglu AK, (2004). Genotyping of Lactococcus garvieae strains from rainbow trout (Oncorhynchus mykiss) by $16 \mathrm{~S}$ rDNA sequencing. Bull Europ Assoc Fish Pathol. 24(2), 119-125.

3. An Y, Friedman RJ, (2000). Handbook of Bacterial Adhesion: Principles, Methods and Applications, Totowa, New Jersey, Humana Press.

4. Balcázar JL, Blas I, Ruiz-Zarzuela I, Cunningham D, Vendrell D, Muzquiz JL, (2006). The role of probiotics in aquaculture. Vet Microbiol. 114, 173-186.

5. Balcázar JL, Vendrell D, De Blas I, Ruiz-Zarzuela I, Gironés O, Múzquiz JL, (2007). In vitro competitive adhesion and production of antagonistic compounds by lactic acid bacteria against fish pathogens. Vet Microbiol.122, 373-380.

6. Balcázar JL, Vendrell D, De Blas I, Ruiz-Zarzuela I, Mu'zquiz JL, Girone's O, (2008). Characterization of probiotic properties of lactic acid bacteria isolated from intestinal microbiota of fish. Aquaculture 278,188-191.
7. Brunt J, Newaj-Fyzul A, Austin B, (2007). The development of probiotics for the control of multiple bacterial diseases of rainbow trout, Oncorhynchus mykiss (Walbaum). J Fish Dis. 30, 573-579.

8. Dharmaraj R, Rajendren V, (2014). Probiotic assessment of Bacillus infantis isolated from gastrointestinal tract of Labeo rohita. Int J Sci Res Pub. 4(7), 1-6.

9. Didinen BI, Metin S, Onuk EE, Takmaz H, Ersoy AT, (2014). Isolation and characterization of potential probiotic bacteria from Rainbow Trout Oncorhynchus mykiss (Walbaum) rearing units against bacterial pathogens. Isr J Aquacult. 66 , $1-8$.

10. Didinen BI, Onuk EE, Metin S, Cayli O, (2017). Identification and characterization of lactic acid bacteria isolated from rainbow trout (Oncorhynchus mykiss, Walbaum 1792), with inhibitory activity against Vagococcus salmoninarum and Lactococcus garvieae. Aquaculture Nut. 00, 1-8 (DOI: 10.1111/anu.12571).

11. Diler Ö, Altun S, Adiloğlu AK, Kubilay A, Işı1klı BI, (2002). First occurrence of Streptococcosis affecting farmed Rainbow Trout (Oncorhynchus mykiss) in Turkey. Bull Eur Ass Fish Pathol. 22(1), 21-26.

12. Ganguly S, Paul I, Mukhopadhayay SK, (2010). Application and effectiveness of immunostimulants, probiotics, and prebiotics in Aquaculture, A Review. Isr J Aquacult. 62(3), 130-138.

13. Hjelm M, Bergh O, Riaza A, Nielsen J, Melcheiorsen J, Jensen S, Duncan H, Ahrens P, Birkbeck H, Gram L, (2004). Selection and identification of autochthonous candidate probiotic bacteria from Turbot larvae (Scophthalmus maximus) rearing units system. Appl Microbiol. 27, 360-371.

14. Irianto A, Austin B, (2002). Use of probiotics to control furunculosis in rainbow trout, Oncorhynchus mykiss (Walbaum). J Fish Dis. 25, 333-342.

15. Kusuda R, Salati F, (1999). Enterococcus seriolicida and Streptococcus iniae. In "Fish Diseases and Disorders" Vol, 3, Viral, Bacterial and Fungal Infections (Woo and Bruno, Eds.), CABI Publishing, pp. 303-312.

16. Lavelle EC, Haris JE, (1997). The processing of an orally administered protein antigen in the digestive tract of rainbow trout, Oncorhynchus mykiss. Compar Biochem Physiol A. 117, 263-275.

17. Mujeeb RKM, Jesmi Y, Thomas AP, Mohamed HAA, (2010). Probiotic effect of Bacillus NL110 and Vibrio NE17 on the survival, growth performance and immune response of Macrobrachium rosenbergii (de Man). Aquacult Res. 41, 120-134.

18. Nikoskelainen S, Salminen S, Bylund G, Ouwehand A, (2001). Characterization of the properties of human and dairy-derived probiotics for prevention of infectious diseases in fish. Appl Environ Microbiol. 67, 2430-2435.

19. Öztürk T, Didinen BI, Doğan G, Özer A, Bircan R, (2013). Lactococcosis in Rainbow Trout (Oncorhynchus mykiss, Walbaum, 1792) in the Middle Black Sea Region in Turkey and antimicrobial susceptibility of the aetiological agent, Lactococcus garvieae. Etlik Vet Mikrobiyol Derg. 24, 7-12. 
20. Perez-Sanchez T, Balcazar JL, Garcia Y, Halaihel N, Vendrell D, De Blas I, Merrifield DL, Ruiz-Zarzuela I, (2011). Identification and characterization of lactic acid bacteria isolated from rainbow trout, Oncorhynchus mykiss (Walbaum) with inhibitory activity against Lactococcus garvieae. J Fish Dis. 34, 499-507.

21. Rinkinen M, (2004). Methods for assessing the adhesion of probiotic and canine gut-derived lactic acid producing bacteria to the canine intestinal mucosa in vitro and measuring mucosal secretory IgA, Academic dissertation. PhD Thesis, Faculty of Veterinary Medicine, University of Helsinki, Finland.

22. Sansawat A, Thirabunyanon M, (2009). Anti-Aeromonas hydrophila activity and characterisation of novel probiotic strains of Bacillus subtilis isolated from the gastrointestinal tract of giant freshwater prawns. Maejo Int J Sci Technol. 3(1), 77-87.
23. Sharma KK, Soni SS, Meharchandani S, (2006). Congo red dye agar test as an indicator test for detection of invasive bovine Escherichia coli. Vet Arhiv. 76, 363-366.

24. Vendrell D, Balca'zar JL, Ruiz-Zarzuela I, de Blas I, Girone's O, Mu'zquiz L, (2006). Lactococcus garvieae in fish: a review. Comp Immunol Microbiol Infect Dis. 29, 177-198.

25. Verschuere L, Rombaut G, Sorgeloos P, Verstraete W, (2000). Probiotic bacteria as biological control agents in aquaculture. Microbiol Mol Biol Rev. 64, 655-671.

26. Vine NG, Leukes WD, Kaiser H, Daya S, Baxter J, Hecht $\mathrm{T}$, (2004). Competition for attachment of aquaculture candidate probiotic and pathogenic bacteria on fish intestinal mucus. J Fish Dis. 27, 319-326.

27. Zlotkin A, Eldar A, Ghittino C, Bercovier H, (1998). Identification of Lactococcus garvieae by PCR. J Clin Microbiol. 36, 983-985. 